\title{
Psychological Variables among Physics Students in Senior Secondary Schools in Osun State, Nigeria
}

\author{
Thomas Ajibade Adebisi
}

\begin{tabular}{l} 
ARTICLE INFO \\
\hline Article History: \\
Received \\
23.05.2020 \\
Received in \\
revised form \\
05.08.2021 \\
Accepted Tarih \\
girmek için buray1 \\
tıklatın. \\
Available online \\
26.05.2020
\end{tabular}

\begin{abstract}
The study investigated levels of psychological variables of academic stress, anxiety and self-efficacy among physics students in senior secondary schools in Osun State, Nigeria. It further examined differences in psychological variables of academic stress, anxiety and self-efficacy between male and female Physics students towards learning of Physics. A descriptive survey research design was employed. A sample of 400 Physics students from 20 senior secondary II (SS2) selected through multistage sampling procedure was used for the study. A researcher- designed and validated questionnaire was administered to the respondents. Mean and standard deviation were used to answer the research question while the null hypothesis was tested at 0.05 level of significance, using t-test. The findings indicated that physics students had moderate level of academic stress, anxiety and self-efficacy. However, there were no significant differences between males' and females' psychological variables of academic stress, anxiety and self-efficacy in the learning of physics in senior secondary schools in the study area. Consequently, it was recommended that Physics teachers should try as much as possible to reduce academic stress and anxiety and enhance academic self-efficacy by carrying out formative assessment frequently to discover the challenged and emotional students for further help and girls' fear should be allayed though encouragement. Besides, the teaching of Physics should be done interestingly.
\end{abstract}

(CTUARA Journal. All rights reserved

Keywords: Psychological variables, Physics students, senior secondary school.

\section{$\overline{\text { INTRODUCTION }}$}

Psychology explains the behaviour of humans. This underscores the importance of psychology in human endeavours. Oxford Dictionary defines psychology as the scientific study of the human mind and its functions, especially those affecting the behaviour in a given situation. Although, there is no particular instrument to measure what is going on in humans' mind, behaviours are examined and evaluated to explain mental processes. Researches have shown that the behaviour of students especially in relation to the sciences is greatly influenced by certain psychological or non-cognitive factors (Eduwem, Umoinyang, \& Otu, 2017). Behaviour is a construct that is dynamic and cannot be viewed by still observation. It might be changing, yet observable in the interplay of various activities of an individual. As young and old human beings exhibit behaviours so students in the classroom or outside are not excluded. Science students in senior secondary schools engage in different learning activities. Based on the fact that the teaching of science involves different approaches that is enquiry based so students cannot be stereotyped in learning.

The uniqueness and demand of learning Physics as one of the science subjects in secondary schools stem up challenges from time to time. The expecting nature of calculations in problem solving, appropriating laws and principles to solve questions in the classroom to experimenting where students need to observe, measure, interpret and plot graph are major exercises that call for attention of learners. The study of Physics demands the whole attention of learners both in the laboratory and in the normal classroom. Therefore, the students of Physics are more involving in order to achieve best performance to pursue their further careers in sciences, technology and medicine. However, there are questions to be raised as to the nature of physics as perceived by students and these are: why do some students consider the subject as abstract and difficult? Their answers revealed the extent to which they are challenged by educational instructions received in Physics. This might have a strong connection to behaviour exhibited towards the subject.

The representative of students in sciences such as in Physics is not gender balance in most of the schools and the performance tends to favour more male than female students. Subjects such as Mathematics 
and Physics are become constructed as "masculine", leading to tensions for female students in selecting these subjects and performing well in them (Mendick, 2005). Equally the behaviours of male and female are not alike. Science is not at all gender-blind and is indirectly demonstrated by the persistence of gender stereotypes identifying science and technology with masculinity, to the symbolic exclusion of women (Faulkner, 2007; Wajcman, 2007 and 2000). Male primarily take the original roles of hunters, fighters and protectors while female assumes the qualities of care and sensitivity to others, emotional expressivity and adaptability( Kalnická \& Geller 2001, Ruisel 2004, Renzetti \& Curran, 2003).

\section{Review of Literature}

Psychological variables have tendency to spark up behavioural patterns at any point in time. These factors can influence human mind provoking feelings and cognitive characteristics. Some of the psychological variables are academic related factors of stress, anxiety, self-efficacy and attitude. Stress is commonly used in day to day conversation to mean burnout or pressure. Stress is mainly a physical response conditioned by the symptoms of mental and physical tension or strain (Aafreen, Priya \& Gayathri, 2018). This is obvious that anything that causes mental or physical pressure will have serious and strong impact on mental processes. This is an indication that stress can affect learning. In Nigerian schools where there are challenges of instructional materials in most of the schools and paucity of physics teachers, physics students are under the burden of solving problems without headway. There could be pressure of following practical procedures during the laboratory exercise, and passing examinations with tears from the students. All these threaten students' sensation and can give rise to academic stress. Stress is an intimidating consciousness (Cohen, Kessler \& Gordon, 1997). Generally, stress refers to both psychological pressure perception on one side, and the body's response to it, on the other, involving multiple systems, from decomposition to muscle and memory (Shahzad, Rehman, \& Saqib, 2018). Academic stress is considered to be a part of students' life, therefore, can impact the students coping strategies in accordance with the demands of academic life (Mussarat, Seema \& Hsfsa, 2013). Stress seems to be very common to students' life because they need to ensure their academic survival and prepare themselves for the further career (Yikealo, Tareke \& Karvinen, 2018). However, excessive stress could distract intelligent emotion of the students. When stress is perceived to be excessive students experience physical and psychological impairment (Yikealo, Tareke \& Karvinen, 2018).

Academic anxiety has been long with students especially among science students; this is so because of fear attached to science in the society. Studying Physics has been seen as an uphill task as if the subject is ordained specifically for a set of students. This could give rise to academic anxiety. Anxiety is a prevalent problem in education (Rothman 2004). The nature of physics in secondary schools is perceived by many students as dreadful, so, emotionally students have a little bit of academic anxiety at the beginning of the course as a result of their interactions with their predecessors. Mahato and Jangir (2012) define academic anxiety as a consequence or outcome of biological or emotional reactions that lower concentration level of students during learning. Anxiety arises when students recognise that their cognitive abilities are overwhelmed by academic demands (González, Fernández, \& Paoloni. 2017). Academic Anxiety is much in science than in other fields for the fact of multi-instructional activities that require students' mental engagement. Studies have shown that anxiety could be detriment to learning. Linnenbrink (2007) agrees to the fact that anxiety has tendency to affect students' motivation and undermine their learning.

Self-efficacy is a psychological construct of Alfred Bandura in 1977, a theoretical framework of social cognitive theory of human behaviour. Self-efficacy is defined as someone's belief in his or her own ability to accomplish a specific task successfully (Bandura, 1977). Self-efficacy is central motivational construct for prediction of behaviours ( $\mathrm{Ng}$, Ang, \& Chan, 2008). Academic self-efficacy is defined as the belief students have about their academic capabilities. Self-efficacy is a motivational strength and belief about oneself; an inner drive that can out grown to form attitude of an individual. Self-efficacy is a self-motivation every student must have to keep him or her on the path of learning. Individuals with high self-efficacy are more likely to attempt new behaviours and to persist in those behaviours, thereby, increasing their possibility of achievement (Sherer, Maddux, Mercandante, PrenticeDunn, Jacobs, \& Rogers, 1982). High self-efficacy students look for new challenges and show persistence at tasks resulting to success (Britner, 2008: Zeldin \& Pajarees, 2000). Selfefficacy determines the self- mregulation and adaptability of students to education challenging. Self-efficacy aids high level of psychodynamic activity and adaptability, self-regulation, flexibility and decrease in the level of emotionality, tolerance to unclear circumstances (Belykh, \& Mayramyan, 2016). To achieve in all human endeavours confidence plays a significant role. According to Van Aalst (2005) students know that things are 
more complicated and they are often not satisfied with the level of understanding they achieve in Physics, as a result, they see physics as a loose collection of facts and statements. That is, self-efficacy of the students described by Van Aalst is low to Physics.

\section{Theoretical Framework}

The study is premised on Bandura's social learning theory of reciprocal determinism. Social learning theory (Bandura, 1974; 1977) considers behaviour in terms of reciprocal determinism. That is, there is a cause to every behaviour. The theory encapsulates that observable behaviour, individual factors, and environmental events all operate as interlocking determinants on each other. The individual factors are motivational forces within an individual such as self-efficacy. The environmental events are events that can affect the behaviours of learners; these are social and physical environment. Behaviours of physics students and environment are influencing each other through non -cognitive factor such as self-efficacy and self-regulation. Students employ self-confidence towards learning (self-efficacy) under circumstances of an individual's ideas on the appropriateness and inappropriateness of actions in improving his own behaviours (self-regulation) (Romiro, 2013). Self-regulation can be as a result of modeling and imitation. Thus, SLT extents to both cognitive and behavioural outlines consisting of concentrating in Physics class, solving physics problem and competence in Physics class. That is, from the social learning perspective, psychological functioning involves a continuous reciprocal interaction among behavioural, cognitive, and environmental influences (Bandura, 1978).

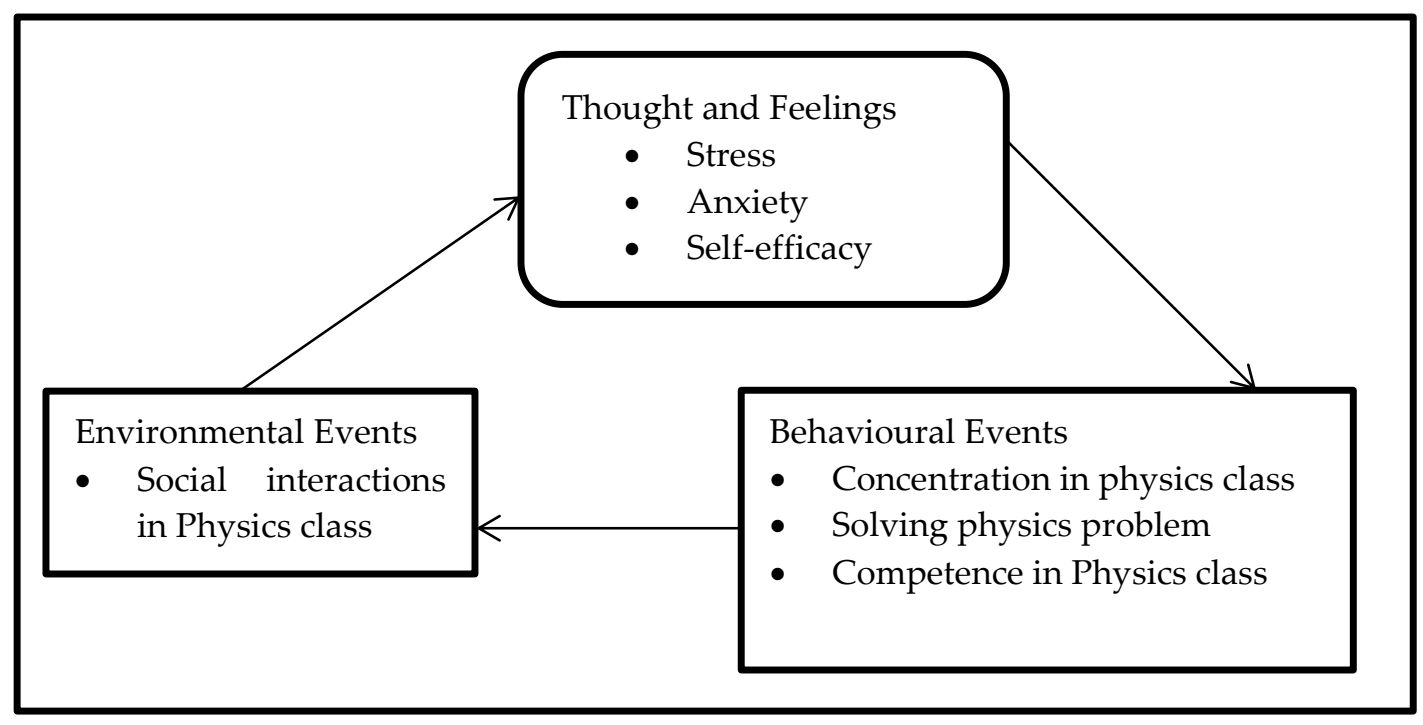

Fig 1: Adapted Theoretical framework based on Bandura's social cognitive theory

\section{Purpose of the Study}

The purpose of this study was to investigate the extent of the presence of psychological variables of academic stress, anxiety and self-efficacy among Physics students in senior secondary schools in Osun State, Nigeria. Specifically, the following objectives guided the study:

(a) to examine level of psychological variables of academic: (i) stress (ii) anxiety, and (iii) self-efficacy that exist among Physics students in senior secondary schools in Osun State, Nigeria.

(b) to compare the difference in psychological variables of academic: i) stress (ii) self-efficacy and (iii) anxiety between male and female Physics students in the learning of Physics in senior secondary schools in Osun State, Nigeria.

\section{Research Questions}

(1)What level of psychological variables of academic: (i) stress (ii) anxiety, and (iii) self-efficacy exist among senior secondary school Physics students in Osun State, Nigeria?

(2)Is there any difference in psychological variables of academic: i) stress (ii) anxiety and (iii) self-efficacy between male and female Physics students in the learning of Physics in senior secondary schools in Osun State, Nigeria?

\section{Hypothesis:}


H0: There is no significant difference in psychological variables of academic: i) stress (ii) anxiety and (iii) self-efficacy between male and female Physics students towards learning of Physics in senior secondary schools in Osun State, Nigeria.

\section{METHODOLOGY}

\section{Research Design}

This study adopted the descriptive survey research design. The design was chosen because the researchers collected information from the sample that was meant to represent the population without any influence.

\section{Participants}

The population for the study comprised all Physics students in public senior secondary schools in Osun State of Nigeria. The sample for the study comprised 400 Physics students selected through multi-stage sampling procedure. Two out of three senatorial districts were randomly selected and used for the study. Five Local Government Areas (LGAs) were randomly selected from each of the two senatorial districts in Osun State. Two schools were selected from each of the LGAs using random sampling technique. The schools selected have number of physics students between 33 and 45 out of which twenty students were selected by first assigning numbers to all the students, thereafter, the number to represent the students were randomly selected with cooperation of class teacher. The selected students were used for the research study.

\section{Research Instrument}

The research instrument used for data collection is titled Psychological Variables Questionnaires (PVQ). The items in the questionnaires were generated based on review of relevant literature related to the constructs under study. The instrument consisted of four parts. Part A contained items on demographic information of the respondents. Part B, C and D each consisted of four items eliciting information on psychological variables of academic stress, academic anxiety and academic self-efficacy respectively. The items were measured on three-point scale of Always, Sometimes and Never. The weighting of items in the positive and negative were scored as follows: positive items, Always $=2$ Sometimes $=1$, and Never $=0$ where negative items were Always $=0$, Sometimes $=1$, and Never $=2 . \quad$ Psychological Variables Questionnaire (PVQ) was validated by two educational psychologists that examined the content validity. The experts unanimously discarded three items out of the initial 15 items presented; four items were also restructured, making a total of 12 items for the study.

\section{Administration of the Instrument}

The researcher administered the questionnaire with the assistance of Physics teachers. The administration was supervised to avoid influence on responses. To avoid mortality, it was collected on the same day.

\section{RESULTS}

The first research question asked, what level of psychological variables of academic: (i) stress (ii) anxiety, and (iii) self-efficacy exist among senior secondary school Physics students in Osun State,Nigeria?

Table 3 shows the responses of physics students to statement on stress influenced items.

Table3. Respondents' Level for Academic Stress

\begin{tabular}{|c|c|c|c|c|c|c|c|}
\hline \multirow[b]{2}{*}{1.} & \multicolumn{3}{|c|}{$\mathrm{S} / \mathrm{N} \quad$ Item } & $\begin{array}{l}\text { Standard } \\
\text { Deviation }\end{array}$ & \multicolumn{2}{|l|}{ Remark } & \\
\hline & $\begin{array}{l}\text { I find } \\
\text { while }\end{array}$ & $\begin{array}{l}\text { difficult to concentrate } \\
\text { olving physics exercises }\end{array}$ & & 0.73 & & Moderate & \\
\hline 2. & I expe & ence fatigue during physics lessons & 1.22 & 1.27 & Moderate & & \\
\hline 3. & Challe & ges of physics are too much to bear & 1.14 & 0.74 & & Moderate & \\
\hline \multirow[t]{2}{*}{4.} & $\mathrm{I} \exp$ & rience mental pressure in physics class. & & 1.28 & 0.76 & & Moderate \\
\hline & $\mathrm{We}$ & ghted Mean & & & & 1.19 & \\
\hline
\end{tabular}

In Table 1, the researcher interpreted mean rating of (0.00- 0.75) as low stress, (0.76- 1.35) moderate stress and (1.36-2.00) as high stress. The table shows moderate academic stress for each of the items 1 to 4, that is, difficulty in concentrating while solving physics exercises, fatigue during physics lessons, and challenges of physics being too much to bear and mental pressure in physics 
class. The weighted mean for all the items is 1.19 . This is indicating that the physics students have moderate academic stress to learning of Physics in senior secondary schools in Osun State, Nigeria.

Table 2 shows the responses of physics students to statement on Academic Anxiety influenced items

Table2. Respondents' Level for Academic Anxiety

S/N Item Mean $\begin{gathered}\text { Standard } \\ \text { Deviation }\end{gathered}$

1. I feel afraid for no reason $\quad 1.20 \quad 0.78 \quad$ Moderate during physics class

2. I worry too much each time I am faced with physics tasks

3. I feel nervous during physics class

0.78

4. I feel restless when I have to take physics examinations

$\begin{array}{lll}1.10 & 0.74 & \text { Moderate } \\ 1.14 & 0.75 & \text { Moderate } \\ 1.21 & 0.87 & \text { Moderate }\end{array}$

Weighted Mean

1.16

The data in Table 2 shows that using the mean rating of (0.00- 0.75$)$ for low anxiety, (0.76- 1.35) for moderate anxiety and (1.36-2.00) for high anxiety. The table shows moderate academic anxiety for each of the items 1 to 4 , that is, being afraid for no reason during physics class, worrying too much each time they are faced with physics tasks, feeling nervous during physics class and restlessness for physics examinations. The weighted mean for all the items is 1.16. This is indicating that the physics students have moderate academic anxiety to learning of Physics in senior secondary schools in Osun State, Nigeria.

Table 3 shows the responses of physics students to statement on Academic Self-efficacy influenced items

Table3. Respondents' Level for Academic Self-efficacy

\begin{tabular}{|c|c|c|c|c|}
\hline $\mathrm{S} / \mathrm{N}$ & Item & Mean & $\begin{array}{l}\text { Standard } \\
\text { Deviation }\end{array}$ & Remark \\
\hline 1. & $\begin{array}{l}\text { I can solve Physics problems } \\
\text { if I try hard enough. }\end{array}$ & 1.13 & 0.78 & Moderate \\
\hline 2. & I am able to think faster & 1.26 & 0.76 & Moderate \\
\hline $\begin{array}{l}3 . \\
4 .\end{array}$ & $\begin{array}{l}\text { when solving Physics problems } \\
\text { I am competent in physics. } \\
\text { I have confidence in solving } \\
\text { words problems in physics }\end{array}$ & $\begin{array}{r}1.38 \\
1.56\end{array}$ & $\begin{array}{l}0.90 \\
0.78\end{array}$ & $\begin{array}{l}\text { High } \\
\text { High }\end{array}$ \\
\hline Weig & ghted Mean & \multicolumn{3}{|c|}{1.33} \\
\hline
\end{tabular}

The data in Table 3 shows that using the mean rating of (0.00- 0.75) for low academic self-efficacy, (0.761.35) for moderate academic self-efficacy and (1.36- 2.00) for high academic self-efficacy. The table shows moderate academic self-efficacy response for items 1 to 2. That is, I can solve Physics problems if tried hard enough and ability to think faster when solving with physics problems; for items 3 to 4 on competence in physics and confidence in solving words problems in physics show high academic self-efficacy. The weighted 
mean for all the items is 1.33 . This means that the physics students have moderate academic self-efficacy to learning of Physics in senior secondary schools in Osun State Nigeria.

\section{Hypothesis}

The hypothesis stated that there is no significant difference in psychological variables of academic: i) stress (ii) self-efficacy and (iii) anxiety between male and female Physics students towards learning of Physics in senior secondary school in Osun State, Nigeria.

The results are presented in Table 4 .

Table 4. t-test of significance between males' and females' psychological variables for academic: stress, anxiety and self-efficacy towards learning of physics.

\begin{tabular}{|c|c|c|c|c|c|c|c|c|}
\hline Psycholo & gical Gender & Mean & $\mathrm{SD} N$ & $\overline{d f}$ & $t$ value & Sig. & Decision & Factors \\
\hline \multirow[t]{2}{*}{ Stress } & Male & 4.74 & 2.218 & 174 & 39 & 0.61 & 0.55 & Not rejected \\
\hline & Female & 4.61 & 2.215 & 226 & & & & \\
\hline \multirow[t]{2}{*}{ Anxiety } & Male & 4.67 & 2.046 & & & 0.40 & 0.69 & Not rejected \\
\hline & Female & 4.59 & 2.215 & & & & & \\
\hline \multirow{2}{*}{$\begin{array}{l}\text { Self- } \\
\text { efficacy }\end{array}$} & Male & 5.02 & 2.048 & & & 1.53 & 0.13 & Not rejected \\
\hline & Female & 4.71 & 2.029 & & & & & \\
\hline
\end{tabular}

Table 4 shows that the difference was found to be non-significant at 0.05 level of probability. Hence the null hypothesis was not rejected, indicating no significant difference between males' and females' psychological variable of academic stress towards learning of physics in senior secondary schools in the study area.

Table 4 shows that $t$ value was found to be non-significant at 0.05 level of probability. Hence the null hypothesis was not rejected, indicating no significant difference between males' and females' psychological variable of academic anxiety towards learning of physics in senior secondary schools in the study area.

Table 4 shows that $\mathrm{t}$ value was found non-significant at 0.05 level of probability. Hence the null hypothesis was not rejected, indicating no significant difference between males' and females' psychological factors of academic self-efficacy towards learning of physics in senior secondary schools in the study area.

\section{DİSCUSSION}

The study that dealt with psychological variables of academic stress, anxiety and self-efficacy among physics students in senior secondary schools in Osun State of Nigeria is quite important to explain the fundamental behaviours of students to learning.

It is obvious that the findings of this study show that physics students exhibit moderate level of academic stress and anxiety towards learning of physics in senior secondary schools in Osun State Nigeria. On the stress variable, this finding is in support of Suresh (2015) who found out that that the higher secondary students are having moderate level of academic stress. The fact remains that the moderate stress is a pressure to perform which according to Erkutlu and Chafra, (2006), the pressure to perform well makes academic environments stressful. Since moderate stress is within the coping limit of students' strength, it cannot break the students away from their academic pursuit. Moderate stress does motivate individuals to achieve and fuel creativity, although stress may hinder performance on difficult tasks ( Auerbach \& Gramling, 1998). Studies have shown that it is excessive stress that dampens academic performance and leads to dropping out and not moderate stress. (Bhattacharya \& Bhattacharya, 2015).

On anxiety factors, this finding corroborates the scope of dimensionality of academic anxiety of Gourav (2015) (2015) which are emotionality, worry, deficits in studying skills and interference generated by a given task. Emotionality is as a result of students feeling afraid for no reason during physics class and nervousness during physics tasks while deficits in studying skills and interference generated by a given task 
are evident in feeling restless to take physics examinations. This finding further agreed with that of Mallow (1988) that anxiety of science is described as fear of science-related situations and tasks in the class.

On self-efficacy variable, this finding contradicts studies of Baanu, Oyelekan and Olurundare (2016) that science students in senior secondary schools in North central of Nigeria had high academic self-efficacy.

The result of the hypothesis tested showed that there is no significant difference between males' and females' psychological variables of academic stress, anxiety and self-efficacy towards learning of physics in senior secondary schools. On academic stress variable, the finding is in contrast with the findings of Suresh (2015) that male students experience higher academic stress than their female counterparts in higher secondary schools. On anxiety variable, the finding contradicts that of Bandalos, Yates and Thorndike-Christ (1995) that female students experience higher levels of academic anxiety than males. On academic self-efficacy, the present study supports the findings of Osuji (2016), Kendra (2015) who found out that there is no significant difference in male and female learning on the influence of self-efficacy. This result corroborates similar findings in the previous studies of Kiran and Sungur (2012) that there was no significant difference between the male and female self-efficacy in the context of learning science among middle school students.

\section{CONCLUSION}

It is evident as far as this study is concerned that physics students in senior secondary schools in Osun State Nigeria have moderate level of academic stress, anxiety and self-efficacy in learning of Physics. However, there is no difference between male and female Physics students in their learning of Physics on the influence of psychological variables of academic stress, anxiety and self-efficacy in secondary schools in Osun State, Nigeria.

\section{RECOMMENDATIONS}

Based on the findings of this study and their implications, the following recommendations are made towards reducing academic stress and anxiety and enhancing academic self-efficacy: Physics teachers should be able to carry out formative assessment frequently to discover challenging and emotional students. The worried and nervous students can be discovered if the Physics teachers can step up to interact with students meaningfully in and outside the classroom. The students in such category could be encouraged and monitored for academic help. Students' fear should be allayed though encouragement especially the girls in Physics class. Teaching Physics should be done interestingly by physics teachers to create less stress and anxiety-filled atmosphere. That is, the teachers should avoid dogmatism approach to teaching. This will assist the students to raise their level of self- efficacy in Physics

\section{REFERENCES}

Aafreen, M. M., Priya, V. V., \& Gayathri, R. (2018). Effect of stress on academic performance of students in different streams. Drug Invention Today, 10(9), 1776-1780.

Auerbach, M. S., \& Gramling, S. E. (1998). Stress management psychological foundations. U.S.A: PrenticeHall,Inc.,

Bandalos, D. L., Yates, K., \& Thorndike-Christ, T. (1995). Effects of math self-concept, perceived self-efficacy, and attributions for failure and success on test anxiety. Journal of Educational Psychology, 87, 611-623.

Bandura, A. (1974). Behavior theory and the models of man. American Psychologist, 29, 859-869.

Bandura, A. (1977). Self-efficacy: Toward a unifying theory of behavioral change. Psychological Review, 84, 191215.

Bandura, A. (1978). The self-system in reciprocal determinism. American Psychologist, 344-358.

Baanu, T. F., Oyelekan, O. S., \& Olurundare, A. S. (2016). Self -efficacy and Chemistry students' academic achievement in senior secondary schools in North-Central, Nigeria. The Malaysian Online Journal of Educational Science, 4(1), 43-52.

Belykh,T. V., \& Mayramyan, A. M. (2016). Integration of formally dynamic properties in the structure of individuality among students with different levels of communicative self-efficacy. Bulletin of the NorthCaucasian Federal, 193-197.

Bhattacharya, R., \& Bhattacharya, B. (2015). Psychological factors affecting students' academic performance in higher education among students. International Journal for Research \& Development in Technology, 4 (1), 63-71.

Britner, S. L. (2008). Motivation in high school science students: A comparison of gender differences in life, physical, and earth science classes. Journal of Research in Science Teaching, 45(8), 955-970. 
Cohen, S., Kessler, R. C., \& Gordon, L. U. (1997). Measuring stress: A guide for health and social scientists. Oxford: University Press on Demand.

Eduwem, J. D., Umoinyang, I. E., \& Otu, B. D. (2017). Psychological factors and secondary schools students' academic performance in Mathematics. IOSR Journal of Research \& Method in Education, 7 (2), 06-13.

Erkutlu, H.V., \& Chafra, J. (2006). Relationship between leadership power bases and job stress of subordinates :Example from boutique hotels, Manage. Res. News, 29(5), 285-297.

Faulkner W. (2007). 'Nuts and Bolts and People'. Gender-troubled engineering identities. Social Studies of Science, 37(3), 331-356.

González, A., Fernández, M. V. C., \& Paoloni, P. V. (2017). Hope and anxiety in physics class: Exploring their motivational antecedents and influence on metacognition and performance. Journal of Research in Science Teaching, 54 (5), 558-585.

Gourav, A. (2015), Academic anxiety of secondary school students in relation to their parental encouragement. International Journal of Research in Humanities and Social Sciences, 3(4), 23-29.

Kalnická, Z. \& Geller, J. L. (2001). Mysel a rod. In: E. Visnovský, M. Popper \& J. Plichtová, (Eds.), Príbehy ohladaní mysle (pp. 184-200). Bratislava, Slovakia: Veda SAV.

Kendra, C. (2015). What is self-efficacy? Teaching and Learning, 34, 75-89

Kiran, D., \& Sungur, S. (2012). Middle school students' science self-efficacy and its sources: Examination of gender difference. Journal of Science Education and Technology, 21, 619-630. https://doi.org/10.1007/s10956-011-9351-y

Linnenbrink, E.A. (2007). The role of affect in student learning: A multi- dimensional approach to considering the interaction of affect, motivation, and engagement. In P. A. Schutz \& R. Pekrun (Eds.), Educational psychology series (pp. 107-124). San Diego, CA: Elsevier Academic.

Mallow, J. (1988). Science Anxiety, Fear of science and how to overcome it. American Journal of Physics, 56 (7), 670

Mahato, B. \& Jangir, S. (2012). A study on academic anxiety among adolescents of Minicoy Island. International Journal of Science and Research (online), 12-14.

Mendick, H. 2005. A beautiful myth? The gendering of being/doing "good at maths". Gender and Education, 17, 203-219

Mussarat, J. K., Seema, A., \& Hsfsa, K. (2013). Effect of perceived academic stress on students' performance. FWU Journal of Social Sciences.7(2), 146-151.

Ng, K. Y., Ang, S., \& Chan, K. Y. (2008). Personality and leader effectiveness: A moderated mediation model of leadership self-efficacy, job demands, and job autonomy. Journal of Applied Psychology, 93, 733-743.

Osuji, U.S. A. (2016). Academic self-efficacy Among open and distance learners in Nigeria. Journal of Educational Foundations, 6(1), 93-102.

Renzetti, C.R. \& Curran, D.J. (2003). Zeny, muzi a spolecnost. Prague, Czech Republic: Karolinum.

Rothman, D. K. (2004). New approach to test anxiety. Journal of College Student,Psychotherapy, 18(4), 45-60.

Romiro, G. B. (2013). The reciprocal determinism of online scaffolding in sustaining a community of inquiry in Physics. Journal of Technology and Science Education. 3(2), 89-97.

Ruisel, I. (2004). Inteligencia a myslenie. Bratislava, Slovakia: Ikar

Shahzad, A. H., Rehman, K. U., \& Saqib, M. (2018). Does stress impact school students' learning performance? Asia Pacif.ic $6^{\text {th }}$ Asia Pacfic Conference on Advanced Research (APCAR-2018, Melbourne, Australia.

Sherer, M., Maddux, J. E., Mercandante, B., PrenticeDunn, S., Jacobs, B., \& Rogers, R. W. (1982). The Selfefficacy scale: Construction and validation. Psychological Reports, 51, 663-671.

Suresh, P.P.(2015). A study on academic stress among higher secondary students. International Journal of Humanities and Social Science Invention, 4(10). 64- 69.

Van Aalst, J. (2000). An introduction to physics education research. Canadian Journal of Physics, 78(1), 57-71 .

Wajcman J. (2000). Reflections on gender and technology studies. In what state is the art? Social Studies of Science, 30 (3), 447-464

Wajcman J. (2007). From Women and Technology to Gendered Technoscience.Information, Communication $\mathcal{E}$ Society, 10(3), 287-298

Yikealo, D., Tareke,W., \& Karvinen, I. (2018).The level of stress among college students: A case in the college of education, Eritrea Institute of Technology. Open Science Journal, 3(4).1-18. 
Adabesi T.A. (2022). Psychological Variables among Physics Students in Senior Secondary Schools in Osun State, Nigeria. The Universal Academic Research Journal,4(1),40-48.

Zeldin, A. L., \& Pajares, F. (2000). Against the odds: Self-efficacy beliefs of women in mathematical, scientific and technological careers. American Educational Research Journal, 37, 215-246. 